\title{
Molecular Pathogenesis of Staphylococcus aureus Infection
}

\author{
George Y. Liu \\ Division of Pediatric Infectious Diseases and the Immunobiology Research Institute, Cedars-Sinai \\ Medical Center, Los Angeles, CA 90048; Department of Pediatrics, University of California, Los \\ Angeles, CA 90025
}

\section{Abstract}

S. aureus has evolved a comprehensive strategy to address the challenges posed by the human immune system. The emergence of community-associated methicillin-resistant $S$. aureus (CAMRSA) infections in individuals with no predisposing conditions suggests an increased pathogenicity of the bacterium, which may be related to acquisition of novel genetic elements. Remarkably, despite an abundance of research, the underlying cause of the epidemic is not known. Here, I review the various strategies used by $S$. aureus to evade obstacles laid out by the human host during colonization and infection. I describe the controversies surrounding MRSA research and discuss how acquisition of the novel genes could explain the increased incidence and severity of CA-MRSA diseases.

S. aureus has an extraordinary repertoire of virulence factors that allows it to survive extreme conditions within the human host. Such an elaborate armamentarium might prompt one to speculate that human kind would be no match for this pathogen and could be highly vulnerable to severe $S$. aureus infection. Surprisingly, S. aureus maintains fine control of virulence expression, and for the most part rarely causes severe infection in previously healthy individuals.

The past ten years however have witnessed the emergence of new clones of MRSA that have rapidly spread across continents, causing rampant skin and soft tissue infections and some unusually severe diseases. Unlike traditional MRSA clones which are largely confined to healthcare settings and prey on immunocompromised hosts or hosts with predisposing factors, these community-associated methicillin-resistant $S$. aureus (CA-MRSA) clones infect previously healthy hosts, particularly children, young and middle aged adults.

This review is written with clinician scientists as the target audience. To impart a better appreciation of MRSA pathogenesis, I will first describe the obstacles $S$. aureus needs to overcome to establish an infection, then highlight aspects of pathogenesis that are unique to healthcare-associated MRSA (HA-MRSA) and CA-MRSA. Readers are referred to many excellent reviews of $S$. aureus colonization and pathogenesis (1-6) that describe more fully the mechanisms of virulence.

Copyright @ 2009 International Pediatic Research Foundation, Inc. All right reserved.

George Y. Liu, M.D. Ph.D., Division of Pediatric Infectious Diseases, Cedars-Sinai Medical Center, 8700 Beverly Blvd. NT4221, Los Angeles, CA 90048, Telephone: 310-423-4471, Fax: 310-423-8284, Email: george.liu@ cshs.org.

Publisher's Disclaimer: Pediatric Research Articles Ahead of Print contains articles in unedited manuscript form that have been peer-reviewed and accepted for publication. As a service to our readers, we are providing this early version of the manuscript. The manuscript will undergo copyediting, typesetting and review of the resulting proof before it is published in its final definitive form. Please note that during the production process errors may be discovered, which could affect the content, and all legal disclaimers that apply to the journal pertain. 


\section{COLONIZATION}

S. aureus acquired from an external source could be the cause of an infection when inoculated into an open wound. More commonly, the human host is infected by bacteria that colonize her or his skin or mucosal surface $(7,8)$. The mucosal surfaces that harbor $S$. aureus include the nose, throat, vaginal wall, and GI tract. Nasal carriage is probably most important because nose-picking could effectively disseminate the bacterium to other body surfaces and other hosts (9). Remarkably, 20\% of individuals are persistently colonized in the nose and $30 \%$ are transiently colonized. The definition of persistent and transient carriage varies according to the study, but generally is described as a single positive culture on a nasal swab (transient) versus at least two consecutive positive cultures one week apart (persistent). Colonization is also more frequent among younger children, and patients with HIV and diabetes (4).

Though colonization predisposes an individual to $S$. aureus infection, one study shows that following nosocomial infection, colonized individuals have less severe $S$. aureus disease compared to non-colonized individuals (7). This begs the question whether colonization could induce low-level adaptive immunity so that subsequent infections become milder. In support of this view, a study showed that carriage of S. aureus harboring the Toxic Shock Syndrome Toxin (TSST) is associated with production and maintenance of antibody to the toxin (10). Conversely, most individuals who acquire Staphylococcus toxic shock syndrome do not have antibody to TSST.

For $S$. aureus, colonization of the human nose presents a significant challenge that requires not only adherence to nasal epithelial cells, but also an ability to cope with host defense and competing resident microorganisms. S. aureus adheres and invades host epithelial cells using a variety of molecules that are collectively termed MSCRAMM (Microbial surface components recognizing adhesive matrix molecules). A number of bacterial products (including MSCRAMM) have been suggested to be important for adhesion and attachment to nasal epithelial cells, but two factors (clumping factor B and wall-associated teichoic acid) have so far proven roles in nasal colonization of humans and rats $(11,12)$.

Host immune deterrents for bacterial nasal colonization include antimicrobial peptides, lysozyme, lactoferrin, and IgA (4). However, little is known of the critical host defenses against $S$. aureus colonization. A study in mice has identified the cystic fibrosis transmembrane conductance regulator and toll like receptor 2, but not toll like receptor 4 as important factors controlling $S$. aureus carriage(13).

Resident nasal flora present an equally formidable challenge for S. aureus. Studies of $S$. aureus carriers and non-carriers have shown that presence of certain bacteria, such as corynebacterium, S.epidermidis or S. pneumoniae, could preclude carriage of S. aureus (14). Introduction of the $S$. pneumoniae vaccine, for example, has been shown in some studies (15), but not others (16), to lead to a significant increase in $S$. aureus colonization leading some to speculate that $S$. pneumoniae and $S$. aureus could compete for the same niche. The general mechanism of niche competition is proposed to be a bacterial competition for adhesion to the same host receptor. In addition, certain competitors such as $S$. pneumoniae secrete hydrogen peroxide which at high concentration suppresses $S$. aureus growth (17). S. aureus could counter by secreting catalase and likely other antioxidants which neutralize hydrogen peroxide(18).

Once colonization is established, S. aureus is positioned in close proximity to the throat, ears, mouth and sinus; yet, surprisingly nasal carriage rarely leads to overt infection of these sites. Studies of $S$. aureus regulation suggest that during colonization, many $S$. aureus virulence genes may be downregulated (19). Among the genes that control S. aureus 
colonization and virulence, the best known global regulator is the accessory gene regulator $a g r$ which has been described in details in many excellent reviews (19). Briefly, agr is a quorum sensing locus, which directly controls expression of a number of virulence and colonizing factors. Downregulation of $a g r$ is associated with colonization and activation of agr with host invasion. A critical question then is what triggers activation of $S$. aureus virulence genes to initiate infection.

\section{PATHOGENESIS}

Infections occur frequently as a consequence of $S$. aureus inoculation into an open wound. Alternatively, in the upper airway, viral infection damages mucosal linings and predisposes the host to $S$. aureus pneumonia, which classically presents a week after onset of influenza infection.

Initial exposure of $S$. aureus to host tissues beyond the mucosal surface or skin is thought to trigger upregulation of virulence genes (19). For the host, resident phagocytes and epithelial cells in the skin or mucosal tissue respond to either bacterial products or tissue injury by activation of the immune system. $S$. aureus peptidoglycan and lipoprotein are sensed by host pattern recognition molecules $(20,21)$; hyaluronan breakdown products (22) and endogenous toll like receptor ligands (RNA, DNA, HMGB1) released by necrotic tissues $(23,24)$ during infection further augment pro-inflammatory signaling leading to local immune cell activation, and neutrophil and macrophage recruitment.

S. aureus has been generally recognized to survive well both inside and outside of host cells. In the extracellular milieu, $S$. aureus must overcome opsonization by complement and antibodies, which directly or indirectly leads to killing of $S$. aureus or uptake by phagocytes through Fc or complement receptors. S. aureus avoids opsonophagocytosis by expressing on its surface a capsule, clumping factor A, protein A, and a number of complement inhibitors, all of which inactivate or prevent host opsonins from binding or targeting the bacterium for destruction $(3,6)$ (Fig. 1).

S. aureus can shelter within epithelial cells, endothelial cells, and even macrophages (25). By contrast, neutrophils present a more formidable challenge to $S$. aureus, as is evidenced by increased incidence of invasive $S$. aureus infections in patients with neutrophil dysfunctions (e.g. Chronic Granulomatous Disease and Leucocyte Adhesion Deficiency). $S$. aureus deploys a number of strategies to resist neutrophil killing. First, it secretes two molecules, CHIP (Chemotaxis Inhibitory Protein) and Eap (Extracellular adherence protein), which respectively block neutrophil recognition of chemotactic factors (26) and neutrophil binding to endothelial adhesion molecule ICAM-1 (27). Inhibition of ICAM-1 binding prevents leukocyte adhesion, diapadesis, and extravasation from the bloodstream to the site of infection.

Upon arriving at the infection site, neutrophils unleash a battery of antimicrobial substances, including antimicrobial peptides, reactive oxygen species (ROS), reactive nitrogen species (RNS), proteases, and lysozyme. Defense against ROS is mediated in $S$. aureus by deployment of a large number of antioxidant enzymes (e.g. catalase, pigment, superoxide dismutase) that neutralize ROS and RNS (3). Antimicrobial peptides which rely partly on targeting of negatively charged bacteria are repelled by $S$. aureus strategies that alter its surface charges $(28,29)$. Additionally, antimicrobial peptides are degraded (aureolysin) (30) and neutralized (staphylokinase) (31).

As a preemptive measure, $S$. aureus counters by secreting specific toxins, which lyse neutrophils. S. aureus expresses a large number of two-component toxins (32) many of which have specificity for human but not mouse cells, therefore many of their functions 
have not been characterized. The recently identified phenol soluble modulin (PSM) is a group of bacterial peptides previously described in S. epidermidis, which induce inflammation and neutrophil cytolysis. The virulence role of PSM peptides has been confirmed in a CA-MRSA skin infection model (33).

Apart from evasion of host immune defense, bacterial survival within the human host is dependent on successful acquisition of nutrients, particularly iron (34). During infection, 95\% of iron is sequestered within host cells and serum iron is mostly bound to host proteins that are not easily accessed. S. aureus secretes high affinity iron-binding compounds (aureochelin and staphyloferrin) during iron starvation $(35,36)$. Additionally, upon sensing low iron, S. aureus initiates transcription of an iron acquisition program (isd) that allows capture of heme and haptoglobin on the cell surface, transport of the-iron complex across the plasma membrane and subsequent oxidative degradation of the heme within the cytoplasm (34).

A severe bacterial infection normally induces the host to mount an adaptive immune response within seven to ten days to limit the ongoing infection and prevent future reinfections. However, one of the hallmarks of $S$. aureus biology is the ability of the pathogen to infect the human host repeatedly throughout life. The mechanism underlying evasion of adaptive immune response is poorly understood, however studies have shown that staphylococcal enterotoxins, TSST, and Eap (a MHC class II analog) could all alter T cell functions by targeting the $\mathrm{T}$ cell receptor activation pathway $(37,38)$. This has been construed as a tactic devised by $S$. aureus to prevent development of long term memory. Likewise, protein A has been shown to deplete splenic marginal zone B cells, which are precursors to B cells (39). The results could be poor generation of specific B cell response. These mechanisms, coupled with strategies described above to block effective antibody binding to bacterial surface, could be important underlying reasons why we remain susceptible to $S$. aureus infections throughout our lives.

Other virulence mechanisms of clinical significance include biofilm formation which allows S. aureus to persist on plastics and resist host defenses or antibiotics(3), and small colony variants which help $S$. aureus survive in a metabolically inactive state under harsh conditions. Small colony variants have been implicated in chronic infections such as chronic osteomyelitis (40).

\section{MRSA PATHOGENESIS}

MRSA deserves separate consideration in $S$. aureus pathogenesis because it is associated with distinct epidemiology, particularly morbidity and mortality. Remarkably, it is estimated that the number of invasive diseases and deaths attributable to MRSA in 2005 are 94,360 and 18,650 in the United States, eclipsing mortality attributed to HIV (41). MRSA can be divided into HA-MRSA and CA-MRSA, two genotypically dissimilar groups of bacteria that target different but overlapping populations and cause different diseases.

\section{HA-MRSA}

MRSA first emerged in the 1960's but became increasingly problematic in the 1990's especially in intensive care unit settings where it became a major cause of nosocomial infections (42). HA-MRSA harbors large staphylococcal chromosome cassettes (SCCmec types I-III), which encode one (SCCmec type I) or multiple antibiotic resistance genes (SCCmec type II and III). Resistance to antibiotics may have allowed the bacterium to survive an environment where antibiotic use is frequent. 
Interestingly, when removed from the healthcare setting, HA-MRSA rarely causes diseases in individuals without predisposing conditions. It has therefore been suggested that HAMRSA represents less robust strains of $S$. aureus that could only survive environments where bacterial competition is limited by antibiotic pressure (43). In support of this viewpoint, HA-MRSA shows a longer generation time compared to methicillin-sensitive $S$. aureus (MSSA) (30 minutes for HA-MRSA versus 23 minutes for MSSA) (44). In a small study, HA-MRSA strains showed increased susceptibility to killing by neutrophils and were less pathogenic when administered to mice systemically (45). Furthermore, direct comparison of CA-MRSA and HA-MRSA strains showed that HA-MRSA expressed lower levels of PSM peptides(33), thereby pointing to a possible defect in HA-MRSA virulence regulation. Consistent with the last finding, many clinical HA-MRSA isolates exhibit a $a^{-} r^{-}$ or a mixed $a g r^{+}$and $a g r^{-}$genotype(46). Though these genotypes could explain the relative nonpathogenic nature of HA-MRSA toward immunocompetent hosts, it is possible that an $a g r^{-}$or a mixed $a g r^{+}$and $a g r^{-}$genotype could be beneficial for HA-MRSA survival in the healthcare setting; $\mathrm{agr}^{-}$genotype could for example facilitate biofilm formation (47)and proliferation on plastic tubings.

As physicians attempt to grapple with the antibiotic resistance problem posed by HAMRSA, increasingly there are reports of the more virulent CA-MRSA infiltrating the healthcare setting $(41,48)$. The impact of this migration bears more careful monitoring as it may demand more aggressive and different control and treatment strategies.

\section{CA-MRSA}

Until the late 1990's MRSA infections were largely confined to immunocompromised individuals or individuals with healthcare exposure. In 1997, death of four healthy children from MRSA pneumonia and sepsis heralded the arrival of a new type of MRSA (49). Soon thereafter, MRSA cases burgeoned across continents; the majority of cases were confined to few clonal lineages that were markedly different from HA-MRSA, shared a small sized Type IV SCCmec cassette, and encoded the genes for the Panton-Valentine Leukocidin (PVL) (50).

CA-MRSA strains were responsible for a dramatic increase in the incidence of infections, particularly of the skin and soft tissue $(51,52)$ and were the cause of many unusually severe infections such as necrotizing pneumonia, necrotizing fasciitis, and myositis (53-55). The change in the clinical manifestations of $S$. aureus prompted speculation that CA-MRSA infections reflected infection by more virulent strains. Few comparative study of CA-MRSA versus MSSA virulence have been performed, and it is not clear whether all CA-MRSA clones are more virulent $(56,57)$. However, one CA-MRSA clone, USA300 has proven to be particularly successful (58), spreading rapidly to become the dominant clone in most regions of the United States, and appearing in Canada and Europe. Many reports have linked USA300 to more severe infections of the bone, skin and soft tissue $(55,57)$. Therefore, studies of USA300 could provide important information on pathogenesis of CA-MRSA.

The epidemiologic findings, though suggestive of a more virulent phenotype, need to be interpreted with caution. Specifically, increased CA-MRSA disease incidence could be attributed to 1) enhanced environmental survival (fomites, pets), 2) increased transmission, 3) more robust colonization, 4) lowered bacterial threshold to activate virulence genes, and 5) increased pathogenicity during infection. Multiple analyses of USA300 outbreaks suggest that the CA-MRSA clone may have enhanced transmission through skin-skin contact or skin-fomite contact $(58,59)$. In a study of men who had sex with men, high rate of perineal, buttock, and genital infections with USA300 suggests this clone has higher transmission efficacy (59). Further, a comparison of skin colonization rate among HA-MRSA, CA- 
MRSA, and MSSA infected patients demonstrated that CA-MRSA infected individuals had significantly higher rate of skin colonization (58). Epidemiologic evidence to support greater pathogenicity of CA-MRSA compared to MSSA is available from a prospective review of osteomyelitis in children (57). In that study, children identified to have $\mathrm{PVL}^{+} \mathrm{CA}-\mathrm{MRSA}$ infections had higher levels of inflammation markers (C reactive protein and sedimentation rate) on admission thereby excluding possible confounding effect of antibiotic treatment on disease outcome (57). Together, these studies suggest that clones such as USA300 are particularly successful because they are transmitted more easily, colonize better, and are more pathogenic.

Among putative virulence factors proposed to be the major determinant of the CA-MRSA epidemic, PVL has been most extensively studied $(1,2,60)$. PVL was found in the phage type 80/81 epidemic $S$. aureus strain that caused high incidence of infections in the 1950's (61), and is found in most clones of CA-MRSA (50). It has been linked in many case series to severe necrotizing pneumonia (62), furunculosis (63), and severe osteomyelitis (57). The two component toxin, when injected into rabbits or mice, produced significant inflammation and necrosis $(64,65)$, and has shown an ability to induce neutrophil cytolysis (66), apoptosis (67), or secretion of pro-inflammatory molecules depending on culture conditions (68).

However, direct demonstration of a virulence role has been conflicting (69-71). LabandeiraRey and coworkers showed PVL is a major virulence determinant in a mouse necrotizing pneumonia model using laboratory strains into which a PVL expressing vector is introduced (65). By contrast, Voyich, and Bubeck Wardenburg used PVL mutants in the background of USA300 and USA400 and found either no difference (71) or a protective effect conferred by PVL (69). It is possible that mice represent a less sensitive model compared to the human host since mouse leukocytes, the target of PVL activity, show reduced sensitivity to PVL lysis compared to human leukocytes (66). We have recently tested this hypothesis by generating PVL mutants in the background of two USA300 necrotizing fasciitis isolates. In a model of severe soft tissue infection, we showed that $\mathrm{PVL}^{+}$necrotizing fasciitis USA300 strains caused more significant muscle injury compared to the PVL- isogenic mutant strains (Tseng and Liu unpublished data). We speculate that use of higher inocula or more sensitive animal models could be the key for uncovering a PVL threshold effect.

The type I arginine catabolic mobile element (ACME) has many properties that make it an equally attractive candidate to explain the success of USA300 (72). ACME is believed to be horizontally transferred from ubiquitous skin commensal $S$. epidermidis (reviewed in 1). It encodes multiple genes, but two gene clusters, $\operatorname{arc}$ (arginine deiminase system) and opp-3 (ABC-transporter), are of particular interest. The arginine deiminase system has been shown in certain bacteria to catabolize L-arginine to provide a source of ATP and could raise the $\mathrm{pH}$ of acidic human skin to one more suitable for bacterial colonization (1). Opp-3 is a member of the $\mathrm{ABC}$ transporter family implicated in multiple functions that could benefit bacterial survival on the skin surface, including peptide nutrient uptake, eukaryotic cell adhesion, and resistance to antimicrobial peptides. Thus, acquisition of ACME by S. aureus, a transient colonizer of the skin, may allow CA-MRSA to colonize the skin on a permanent basis, thereby enhancing the likelihood of a skin infection occurring upon any disruption of the skin barrier. Evidence that CA-MRSA colonizes the skin better compared to MSSA and HA-MRSA has been provided by Miller and coworkers (58). So far, there has been no direct evidence that ACME contributes to skin colonization.

PSM peptides have been described previously to contribute to CA-MRSA skin infection in mice (33). Though not unique to CA-MRSA, PSM peptides are expressed at higher level in CA-MRSA compared to HA-MRSA, which prompts suggestion that differences in global virulence regulation could be an important factor in CA-MRSA virulence. Montgomery and coworkers showed that among CA-MRSA, USA300 strains are more pathogenic than 
USA400 strains (73). The difference in virulence correlated with higher expression of multiple virulence genes by USA300 strains compared to USA400 strains.

Many other putative virulence factors uniquely expressed by CA-MRSA strains remain to be explored $(50,72)$. How each product could add to the pathogenicity of the specific strain is not known. However, if Occam's razor, the principle of diagnostic parsimony frequently used in clinical decision making, is to guide the assessment of CA-MRSA pathogenesis, it is likely that one or very few factors are ultimately responsible for the simultaneous emergence of several CA-MRSA epidemic clones.

\section{FUTURE DIRECTION}

The emergence of CA-MRSA heralded an era of uncertainty in public health and patient care as antibiotic resistance and virulence converged to create a major health crisis. As the epidemic evolved and expanded, research has strived to achieve the following goals: 1) identify the cause and mechanism underlying the epidemic; 2) develop antibiotics that do not promptly become obsolete; 3 ) develop an effective vaccine. So far, the goals have met with varying degrees of success.

Our understanding of CA-MRSA epidemic is still limited despite an abundance of epidemiologic and basic studies. Most fundamentally, we do not know what makes the bacterium more pathogenic. Study of S. aureus will require the development of animal models that more closely approximate human infections. $S$. aureus is not a natural colonizer of mice; therefore, many of the virulence factors elaborated by S. aureus to evade the human immune system may prove more difficult to study in mice, with PVL being a prime example. Though there continues to be an important place for traditional mouse research which allows manipulation of the host immune factors using already generated knockout mice, a model that simulates human disease could be achieved by use of other animals or by development of partially humanized mouse models, in which the mouse innate or adaptive immune system is replaced by its human counterpart (74).

As discussed above, mechanisms other than virulence could explain the increased CAMRSA disease incidence and severity. Therefore, study of bacterial factors must be expanded to assays beyond traditional virulence testing, including colonization, resistance to environmental stimuli, as guided by epidemiologic findings. These studies would optimally involve collaboration between epidemiologists and basic researchers.

In recent years, the threat posed by antibiotic resistant $S$. aureus has refueled research effort to discover novel classes of antibiotics. Because traditional drug library screens have been slow to identify new antibiotics, an alternative strategy has been the targeting of important virulence factors. As an example, we have demonstrated that the S. aureus golden pigment is a virulence factor because it shields the bacterium from host oxidant killing (75). Because S. aureus pigment and human cholesterol share synthesis of a common precursor, we have been able to identify a human cholesterol inhibitor that blocked $S$. aureus pigmentation and reduced $S$. aureus virulence in mice (76). Likewise, alpha toxin, which is elaborated by many but not all clinical $S$. aureus strains, has demonstrated virulence function in a CAMRSA model of lung infection, and application of specific antibodies against alpha toxin has been shown to significantly ameliorate lung injury (77). These virulence-based strategies could prove to be useful adjuncts to traditional therapeutics.

Ultimately, an effective vaccine is needed to solve the MRSA health crisis. At the height of the penicillin resistant $S$. pneumoniae problem eight years ago, introduction of an effective vaccine promptly decreased the incidence of invasive diseases and averted a major health crisis. A similar antibiotic resistance problem was solved by introduction of an effective 
vaccine against $H$. influenzae. However, the MRSA epidemic presents a different and more formidable challenge. For one, $S$. aureus is a more complex organism that is not dependent on a single major virulence factor to cause disease. Its selective upregulation of virulence factors during different phases of infection could render vaccine against a single factor relatively ineffective. The recent failure of active or passive immunization trials against capsular polysaccharide (StaphVAX®), ClfA and SdrG (Veronate $\left.{ }^{\circledR}\right)$ (78) may be evidence of that principle. Therefore, experts have proposed that $S$. aureus vaccine would be more effective if multiple select factors are targeted (reviewed in 78).

A more fundamental issue, with direct implication on vaccine development, is why the human host is persistently susceptible to $S$. aureus infection throughout life. Research has indicated that bacterial products such as protein A and staphylococcal enterotoxins may have roles in modulation of T and B cell functions $(38,39)$; however, adaptive immune evasion mechanisms after $S$. aureus infection remain largely unknown. Understanding of these mechanisms may hold the ultimate key to a successful vaccine.

In summary, S. aureus pathogenesis will remain an intensely important area of research for years to come. Most published studies estimate current CA-MRSA nasal colonization rate at less than 5\% (79,80); therefore, if the rate of colonization continues to rise, the epidemic will likely expand. It is not clear whether over time the human host could develop an adaptive immune response to novel virulence factors expressed by CA-MRSA strains. If those virulence factors contribute significantly to the epidemic, neutralization of those factors may cause the epidemic to subside. If the human immune system is unable to adapt, human kind will need to address the problem through research, and success will depend on the concentration of research effort, funding, and well coordinated multi-disciplinary approaches directed at addressing select key questions.

\section{Acknowledgments}

I thank Dr. Binh Diep, Delores Tseng and Terence Doherty for critical reading of this review.

Financial Support: G. Y. Liu is the recipient of a Burroughs-Wellcome Career Award and a National Institutes of Health grant AI074832.

\section{ABBREVIATIONS}

$a g r$

ACME

CA-MRSA

HA-MRSA

MSSA

PSM

PVL

ROS

SCCmec accessory gene regulator

arginine catabolic mobile element

community-associated methicillin-resistant $S$. aureus

healthcare-associated methicillin-resistant S. aureus

methicillin-sensitive $S$. aureus

phenol soluble modulin

Panton-Valentine Leukocidin

reactive oxygen species

Staphylococcal cassette chromosome mec

\section{References}

1. Diep BA, Otto M. The role of virulence determinants in community-associated MRSA pathogenesis. Trends Microbiol 2008;16:361-369. [PubMed: 18585915] 
2. Gordon RJ, Lowy FD. Pathogenesis of methicillin-resistant Staphylococcus aureus infection. Clin Infect Dis 2008;46:S350-S359. [PubMed: 18462090]

3. Foster TJ. Immune evasion by staphylococci. Nat Rev Microbiol 2005;3:948-958. [PubMed: 16322743]

4. Wertheim HF, Melles DC, Vos MC, van Leeuwen W, van Belkum A, Verbrugh HA, Nouwen JL. The role of nasal carriage in Staphylococcus aureus infections. Lancet Infect Dis 2005;5:751-762. [PubMed: 16310147]

5. van Belkum A, Emonts M, Wertheim H, de Jongh C, Nouwen J, Bartels H, Cole A, Hermans P, Boelens H, Toom NL, Snijders S, Verbrugh H, van Leeuwen W. The role of human innate immune factors in nasal colonization by Staphylococcus aureus. Microbes Infect 2007;9:1471-1477. [PubMed: 17913546]

6. Rooijakkers SH, van Kessel KP, van Strijp JA. Staphylococcal innate immune evasion. Trends Microbiol 2005;13:596-601. [PubMed: 16242332]

7. Wertheim HF, Vos MC, Ott A, van Belkum A, Voss A, Kluytmans JA, van Keulen PH, Vandenbroucke-Grauls CM, Meester MH, Verbrugh HA. Risk and outcome of nosocomial Staphylococcus aureus bacteraemia in nasal carriers versus non-carriers. Lancet 2004;364:703-705. [PubMed: 15325835]

8. von Eiff C, Becker K, Machka K, Stammer H, Peters G. Nasal carriage as a source of Staphylococcus aureus bacteremia. Study Group. N Engl J Med 2001;344:11-16. [PubMed: 11136954]

9. Wertheim HF, van Kleef M, Vos MC, Ott A, Verbrugh HA, Fokkens W. Nose picking and nasal carriage of Staphylococcus aureus. Infect Control Hosp Epidemiol 2006;27:863-867. [PubMed: 16874648]

10. Ritz HL, Kirkland JJ, Bond GG, Warner EK, Petty GP. Association of high levels of serum antibody to staphylococcal toxic shock antigen with nasal carriage of toxic shock antigenproducing strains of Staphylococcus aureus. Infect Immun 1984;43:954-958. [PubMed: 6698614]

11. Wertheim HF, Walsh E, Choudhurry R, Melles DC, Boelens HA, Miajlovic H, Verbrugh HA, Foster T, van Belkum A. Key role for clumping factor B in Staphylococcus aureus nasal colonization of humans. PLoS Med 2008;5:e17. [PubMed: 18198942]

12. Weidenmaier C, Kokai-Kun JF, Kristian SA, Chanturiya T, Kalbacher H, Gross M, Nicholson G, Neumeister B, Mond JJ, Peschel A. Role of teichoic acids in Staphylococcus aureus nasal colonization, a major risk factor in nosocomial infections. Nat Med 2004;10:243-245. [PubMed: 14758355]

13. Gonzalez-Zorn B, Senna JP, Fiette L, Shorte S, Testard A, Chignard M, Courvalin P, GrillotCourvalin C. Bacterial and host factors implicated in nasal carriage of methicillin-resistant Staphylococcus aureus in mice. Infect Immun 2005;73:1847-1851. [PubMed: 15731086]

14. Lina G, Boutite F, Tristan A, Bes M, Etienne J, Vandenesch F. Bacterial competition for human nasal cavity colonization: role of Staphylococcal agr alleles. Appl Environ Microbiol 2003;69:1823. [PubMed: 12513972]

15. Bogaert D, van Belkum A, Sluijter M, Luijendijk A, de Groot R, Rumke HC, Verbrugh HA, Hermans PW. Colonisation by Streptococcus pneumoniae and Staphylococcus aureus in healthy children. Lancet 2004;363:1871-1872. [PubMed: 15183627]

16. Cohen R, Levy C, Thollot F, de La Rocque F, Koskas M, Bonnet E, Fritzell B, Varon E. Pneumococcal conjugate vaccine does not influence Staphylococcus aureus carriage in young children with acute otitis media. Clin Infect Dis 2007;45:1583-1587. [PubMed: 18190319]

17. Regev-Yochay G, Trzcinski K, Thompson CM, Malley R, Lipsitch M. Interference between Streptococcus pneumoniae and Staphylococcus aureus: In vitro hydrogen peroxide-mediated killing by Streptococcus pneumoniae. J Bacteriol 2006;188:4996-5001. [PubMed: 16788209]

18. Park B, Nizet V, Liu GY. Role of Staphylococcus aureus catalase in niche competition against Streptococcus pneumoniae. J Bacteriol 2008;190:2275-2278. [PubMed: 18223076]

19. Novick RP. Autoinduction and signal transduction in the regulation of staphylococcal virulence. Mol Microbiol 2003;48:1429-1449. [PubMed: 12791129] 
20. Hashimoto M, Tawaratsumida K, Kariya H, Kiyohara A, Suda Y, Krikae F, Kirikae T, Gotz F. Not lipoteichoic acid but lipoproteins appear to be the dominant immunobiologically active compounds in Staphylococcus aureus. J Immunol 2006;177:3162-3169. [PubMed: 16920954]

21. Fournier B, Philpott DJ. Recognition of Staphylococcus aureus by the innate immune system. Clin Microbiol Rev 2005;18:521-540. [PubMed: 16020688]

22. Scheibner KA, Lutz MA, Boodoo S, Fenton MJ, Powell JD, Horton MR. Hyaluronan fragments act as an endogenous danger signal by engaging TLR2. J Immunol 2006;177:1272-1281. [PubMed: 16818787]

23. Pisetsky DS. The role of nuclear macromolecules in innate immunity. Proc Am Thorac Soc 2007;4:258-262. [PubMed: 17607009]

24. Cavassani KA, Ishii M, Wen H, Schaller MA, Lincoln PM, Lukacs NW, Hogaboam CM, Kunkel SL. TLR3 is an endogenous sensor of tissue necrosis during acute inflammatory events. J Exp Med 2008;205:2609-2621. [PubMed: 18838547]

25. Kubica M, Guzik K, Koziel J, Zarebski M, Richter W, Gajkowska B, Golda A, Maciag-Gudowska A, Brix K, Shaw L, Foster T, Potempa J. A potential new pathway for Staphylococcus aureus dissemination: the silent survival of $\mathrm{S}$. aureus phagocytosed by human monocyte-derived macrophages. PLoS One 2008;3:e1409. [PubMed: 18183290]

26. de Haas CJ, Veldkamp KE, Peschel A, Weerkamp F, Van Wamel WJ, Heezius EC, Poppelier MJ, Van Kessel KP, van Strijp JA. Chemotaxis inhibitory protein of Staphylococcus aureus, a bacterial antiinflammatory agent. J Exp Med 2004;199:687-695. [PubMed: 14993252]

27. Chavakis T, Hussain M, Kanse SM, Peters G, Bretzel RG, Flock JI, Herrmann M, Preissner KT. Staphylococcus aureus extracellular adherence protein serves as anti-inflammatory factor by inhibiting the recruitment of host leukocytes. Nat Med 2002;8:687-693. [PubMed: 12091905]

28. Peschel A, Jack RW, Otto M, Collins LV, Staubitz P, Nicholson G, Kalbacher H, Nieuwenhuizen WF, Jung G, Tarkowski A, van Kessel KP, van Strijp JA. Staphylococcus aureus resistance to human defensins and evasion of neutrophil killing via the novel virulence factor MprF is based on modification of membrane lipids with 1-lysine. J Exp Med 2001;193:1067-1076. [PubMed: 11342591]

29. Collins LV, Kristian SA, Weidenmaier C, Faigle M, Van Kessel KP, Van Strijp JA, Gotz F, Neumeister B, Peschel A. Staphylococcus aureus strains lacking D-alanine modifications of teichoic acids are highly susceptible to human neutrophil killing and are virulence attenuated in mice. J Infect Dis 2002;186:214-219. [PubMed: 12134257]

30. Sieprawska-Lupa M, Mydel P, Krawczyk K, Wojcik K, Puklo M, Lupa B, Suder P, Silberring J, Reed M, Pohl J, Shafer W, McAleese F, Foster T, Travis J, Potempa J. Degradation of human antimicrobial peptide LL-37 by Staphylococcus aureus-derived proteinases. Antimicrob Agents Chemother 2004;48:4673-4679. [PubMed: 15561843]

31. Jin T, Bokarewa M, Foster T, Mitchell J, Higgins J, Tarkowski A. Staphylococcus aureus resists human defensins by production of staphylokinase, a novel bacterial evasion mechanism. $\mathrm{J}$ Immunol 2004;172:1169-1176. [PubMed: 14707093]

32. Tomita T, Kamio Y. Molecular biology of the pore-forming cytolysins from Staphylococcus aureus, alpha- and gamma-hemolysins and leukocidin. Biosci Biotechnol Biochem 1997;61:565572. [PubMed: 9145511]

33. Wang R, Braughton KR, Kretschmer D, Bach TH, Queck SY, Li M, Kennedy AD, Dorward DW, Klebanoff SJ, Peschel A, DeLeo FR, Otto M. Identification of novel cytolytic peptides as key virulence determinants for community-associated MRSA. Nat Med 2007;13:1510-1514. [PubMed: 17994102]

34. Maresso AW, Schneewind O. Iron acquisition and transport in Staphylococcus aureus. Biometals 2006;19:193-203. [PubMed: 16718604]

35. Drechsel H, Freund S, Nicholson G, Haag H, Jung O, Zahner H, Jung G. Purification and chemical characterization of staphyloferrin $\mathrm{B}$, a hydrophilic siderophore from staphylococci. Biometals 1993;6:185-192. [PubMed: 8400765]

36. Courcol RJ, Trivier D, Bissinger MC, Martin GR, Brown MR. Siderophore production by Staphylococcus aureus and identification of iron-regulated proteins. Infect Immun 1997;65:19441948. [PubMed: 9125585] 
37. Lee LY, Miyamoto YJ, McIntyre BW, Hook M, McCrea KW, McDevitt D, Brown EL. The Staphylococcus aureus Map protein is an immunomodulator that interferes with T cell-mediated responses. J Clin Invest 2002;110:1461-1471. [PubMed: 12438444]

38. Llewelyn M, Cohen J. Superantigens: microbial agents that corrupt immunity. Lancet Infect Dis 2002;2:156-162. [PubMed: 11944185]

39. Goodyear CS, Silverman GJ. Staphylococcal toxin induced preferential and prolonged in vivo deletion of innate-like B lymphocytes. Proc Natl Acad Sci USA 2004;101:11392-11397. [PubMed: 15273292]

40. von Eiff C, Peters G, Becker K. The small colony variant (SCV) concept -- the role of staphylococcal SCVs in persistent infections. Injury 2006;37:S26-S33. [PubMed: 16651068]

41. Klevens RM, Morrison MA, Nadle J, Petit S, Gershman K, Ray S, Harrison LH, Lynfield R, Dumyati G, Townes JM, Craig AS, Zell ER, Fosheim GE, McDougal LK, Carey RB, Fridkin SK. Invasive methicillin-resistant Staphylococcus aureus infections in the United States. JAMA 2007;298:1763-1771. [PubMed: 17940231]

42. Klevens RM, Edwards JR, Tenover FC, McDonald LC, Horan T, Gaynes R. Changes in the epidemiology of methicillin-resistant Staphylococcus aureus in intensive care units in US hospitals, 1992-2003. Clin Infect Dis 2006;42:389-391. [PubMed: 16392087]

43. Eady EA, Cove JH. Staphylococcal resistance revisited: community-acquired methicillin resistant Staphylococcus aureus--an emerging problem for the management of skin and soft tissue infections. Curr Opin Infect Dis 2003;16:103-124. [PubMed: 12734443]

44. Laurent F, Lelievre H, Cornu M, Vandenesch F, Carret G, Etienne J, Flandrois JP. Fitness and competitive growth advantage of new gentamicin-susceptible MRSA clones spreading in French hospitals. J Antimicrob Chemother 2001;47:277-283. [PubMed: 11222560]

45. Voyich JM, Braughton KR, Sturdevant DE, Whitney AR, Said-Salim B, Porcella SF, Long RD, Dorward DW, Gardner DJ, Kreiswirth BN, Musser JM, DeLeo FR. Insights into mechanisms used by Staphylococcus aureus to avoid destruction by human neutrophils. J Immunol 2005;175:39073919. [PubMed: 16148137]

46. Shopsin B, Drlica-Wagner A, Mathema B, Adhikari RP, Kreiswirth BN, Novick RP. Prevalence of agr dysfunction among colonizing Staphylococcus aureus strains. J Infect Dis 2008;198:11711174. [PubMed: 18752431]

47. Vuong C, Saenz HL, Gotz F, Otto M. Impact of the agr quorum-sensing system on adherence to polystyrene in Staphylococcus aureus. J Infect Dis 2000;182:1688-1693. [PubMed: 11069241]

48. Liu C, Graber CJ, Karr M, Diep BA, Basuino L, Schwartz BS, Enright MC, O'Hanlon SJ, Thomas JC, Perdreau-Remington F, Gordon S, Gunthorpe H, Jacobs R, Jensen P, Leoung G, Rumack JS, Chambers HF. A population-based study of the incidence and molecular epidemiology of methicillin-resistant Staphylococcus aureus disease in San Francisco, 2004-2005. Clin Infect Dis 2008;46:1637-1646. [PubMed: 18433335]

49. Four Pediatric Deaths from Community-Acquired Methicillin-Resistant Staphylococcus aureus -Minnesota and North Dakota, 1997-1999. MMWR Morb Mortal Wkly Rep 1999;48:707-710.

50. Vandenesch F, Naimi T, Enright MC, Lina G, Nimmo GR, Heffernan H, Liassine N, Bes M, Greenland T, Reverdy ME, Etienne J. Community-acquired methicillin-resistant Staphylococcus aureus carrying Panton-Valentine leukocidin genes: worldwide emergence. Emerg Infect Dis 2003;9:978-984. [PubMed: 12967497]

51. Moran GJ, Krishnadasan A, Gorwitz RJ, Fosheim GE, McDougal LK, Carey RB, Talan DA. Methicillin-resistant S. aureus infections among patients in the emergency department. N Engl J Med 2006;355:666-674. [PubMed: 16914702]

52. Stryjewski ME, Chambers HF. Skin and soft-tissue infections caused by community-acquired methicillin-resistant Staphylococcus aureus. Clin Infect Dis 2008;46:S368-S377. [PubMed: 18462092]

53. Bradley SF. Staphylococcus aureus pneumonia: emergence of MRSA in the community. Semin Respir Crit Care Med 2005;26:643-649. [PubMed: 16388433]

54. Pannaraj PS, Hulten KG, Gonzalez BE, Mason EO Jr, Kaplan SL. Infective pyomyositis and myositis in children in the era of community-acquired, methicillin-resistant Staphylococcus aureus infection. Clin Infect Dis 2006;43:953-960. [PubMed: 16983604] 
55. Miller LG, Perdreau-Remington F, Rieg G, Mehdi S, Perlroth J, Bayer AS, Tang AW, Phung TO, Spellberg B. Necrotizing fasciitis caused by community-associated methicillin-resistant Staphylococcus aureus in Los Angeles. N Engl J Med 2005;352:1445-1453. [PubMed: 15814880]

56. Miller LG, Quan C, Shay A, Mostafaie K, Bharadwa K, Tan N, Matayoshi K, Cronin J, Tan J, Tagudar G, Bayer AS. A prospective investigation of outcomes after hospital discharge for endemic, community-acquired methicillin-resistant and - susceptible Staphylococcus aureus skin infection. Clin Infect Dis 2007;44:483-492. [PubMed: 17243049]

57. Bocchini CE, Hulten KG, Mason EO Jr, Gonzalez BE, Hammerman WA, Kaplan SL. PantonValentine leukocidin genes are associated with enhanced inflammatory response and local disease in acute hematogenous Staphylococcus aureus osteomyelitis in children. Pediatrics 2006;117:433440. [PubMed: 16452363]

58. Miller LG, Diep BA. Clinical practice: colonization, fomites, and virulence: rethinking the pathogenesis of community-associated methicillin-resistant Staphylococcus aureus infection. Clin Infect Dis 2008;46:752-760. [PubMed: 18220477]

59. Diep BA, Chambers HF, Graber CJ, Szumowski JD, Miller LG, Han LL, Chen JH, Lin F, Lin J, Phan TH, Carleton HA, McDougal LK, Tenover FC, Cohen DE, Mayer KH, Sensabaugh GF, Perdreau-Remington F. Emergence of multidrug-resistant, community-associated, methicillinresistant Staphylococcus aureus clone USA300 in men who have sex with men. Ann Intern Med 2008;148:249-257. [PubMed: 18283202]

60. Boyle-Vavra S, Daum RS. Community-acquired methicillin-resistant Staphylococcus aureus: the role of Panton-Valentine leukocidin. Lab Invest 2007;87:3-9. [PubMed: 17146447]

61. Robinson DA, Kearns AM, Holmes A, Morrison D, Grundmann H, Edwards G, O'Brien FG, Tenover FC, McDougal LK, Monk AB, Enright MC. Re-emergence of early pandemic Staphylococcus aureus as a community-acquired meticillin-resistant clone. Lancet 2005;365:1256-1258. [PubMed: 15811459]

62. Gillet Y, Etienne J, Lina G, Vandenesch F. Association of necrotizing pneumonia with pantonvalentine leukocidin-producing Staphylococcus aureus, regardless of methicillin resistance. Clin Infect Dis 2008;47:985-986. [PubMed: 18778235]

63. Yamasaki O, Kaneko J, Morizane S, Akiyama H, Arata J, Narita S, Chiba J, Kamio Y, Iwatsuki K. The association between Staphylococcus aureus strains carrying panton-valentine leukocidin genes and the development of deep-seated follicular infection. Clin Infect Dis 2005;40:381-385. [PubMed: 15668860]

64. Cribier B, Prevost G, Couppie P, Finck-Barbancon V, Grosshans E, Piemont Y. Staphylococcus aureus leukocidin: a new virulence factor in cutaneous infections? An epidemiological and experimental study. Dermatology 1992;185:175-180. [PubMed: 1446082]

65. Labandeira-Rey M, Couzon F, Boisset S, Brown EL, Bes M, Benito Y, Barbu EM, Vazquez V, Hook M, Etienne J, Vandenesch F, Bowden MG. Staphylococcus aureus Panton-Valentine leukocidin causes necrotizing pneumonia. Science 2007;315:1130-1133. [PubMed: 17234914]

66. Szmigielski S, Prevost G, Monteil H, Colin DA, Jeljaszewicz J. Leukocidal toxins of staphylococci. Zentralbl Bakteriol 1999;289:185-201. [PubMed: 10360319]

67. Genestier AL, Michallet MC, Prevost G, Bellot G, Chalabreysse L, Peyrol S, Thivolet F, Etienne J, Lina G, Vallette FM, Vandenesch F, Genestier L. Staphylococcus aureus Panton-Valentine leukocidin directly targets mitochondria and induces Bax-independent apoptosis of human neutrophils. J Clin Invest 2005;115:3117-3127. [PubMed: 16276417]

68. Konig B, Koller M, Prevost G, Piemont Y, Alouf JE, Schreiner A, Konig W. Activation of human effector cells by different bacterial toxins (leukocidin, alveolysin, and erythrogenic toxin A): generation of interleukin-8. Infect Immun 1994;62:4831-4837. [PubMed: 7927762]

69. Bubeck Wardenburg J, Palazzolo-Ballance AM, Otto M, Schneewind O, DeLeo FR. PantonValentine leukocidin is not a virulence determinant in murine models of community-associated methicillin-resistant Staphylococcus aureus disease. J Infect Dis 2008;198:1166-1170. [PubMed: 18729780]

70. Bubeck Wardenburg J, Bae T, Otto M, Deleo FR, Schneewind O. Poring over pores: alphahemolysin and Panton-Valentine leukocidin in Staphylococcus aureus pneumonia. Nat Med 2007;13:1405-1406. [PubMed: 18064027] 
71. Voyich JM, Otto M, Mathema B, Braughton KR, Whitney AR, Welty D, Long RD, Dorward DW, Gardner DJ, Lina G, Kreiswirth BN, DeLeo FR. Is Panton-Valentine leukocidin the major virulence determinant in community-associated methicillin-resistant Staphylococcus aureus disease? J Infect Dis 2006;194:1761-1770. [PubMed: 17109350]

72. Diep BA, Gill SR, Chang RF, Phan TH, Chen JH, Davidson MG, Lin F, Lin J, Carleton HA, Mongodin EF, Sensabaugh GF, Perdreau-Remington F. Complete genome sequence of USA300, an epidemic clone of community-acquired meticillin-resistant Staphylococcus aureus. Lancet 2006;367:731-739. [PubMed: 16517273]

73. Montgomery CP, Boyle-Vavra S, Adem PV, Lee JC, Husain AN, Clasen J, Daum RS. Comparison of virulence in community-associated methicillin-resistant Staphylococcus aureus pulsotypes USA300 and USA400 in a rat model of pneumonia. J Infect Dis 2008;198:561-570. [PubMed: 18598194]

74. Shultz LD, Ishikawa F, Greiner DL. Humanized mice in translational biomedical research. Nat Rev Immunol 2007;7:118-130. [PubMed: 17259968]

75. Liu GY, Essex A, Buchanan JT, Datta V, Hoffman HM, Bastian JF, Fierer J, Nizet V. Staphylococcus aureus golden pigment impairs neutrophil killing and promotes virulence through its antioxidant activity. J Exp Med 2005;202:209-215. [PubMed: 16009720]

76. Liu CI, Liu GY, Song Y, Yin F, Hensler ME, Jeng WY, Nizet V, Wang AH, Oldfield E. A cholesterol biosynthesis inhibitor blocks Staphylococcus aureus virulence. Science 2008;319:1391-1394. [PubMed: 18276850]

77. Bubeck Wardenburg J, Schneewind O. Vaccine protection against Staphylococcus aureus pneumonia. J Exp Med 2008;205:287-294. [PubMed: 18268041]

78. Schaffer AC, Lee JC. Vaccination and passive immunisation against Staphylococcus aureus. Int J Antimicrob Agents 2008;32:S71-S78. [PubMed: 18757184]

79. Ellis MW, Griffith ME, Dooley DP, McLean JC, Jorgensen JH, Patterson JE, Davis KA, Hawley JS, Regules JA, Rivard RG, Gray PJ, Ceremuga JM, Dejoseph MA, Hospenthal DR. Targeted intranasal mupirocin to prevent colonization and infection by community-associated methicillinresistant Staphylococcus aureus strains in soldiers: a cluster randomized controlled trial. Antimicrob Agents Chemother 2007;51:3591-3598. [PubMed: 17682105]

80. Gorwitz RJ, Kruszon-Moran D, McAllister SK, McQuillan G, McDougal LK, Fosheim GE, Jensen BJ, Killgore G, Tenover FC, Kuehnert MJ. Changes in the prevalence of nasal colonization with Staphylococcus aureus in the United States, 2001-2004. J Infect Dis 2008;197:1226-1234.

[PubMed: 18422434] 


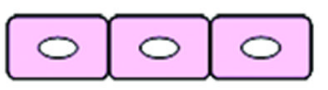

\section{Sequestration within epithelial cells (MSCRAMM)}

$\mathrm{Fe}^{++}$ $\mathrm{Fe}^{++}$

Iron acquisition

(Isd, aureochelin, staphyloferrin )

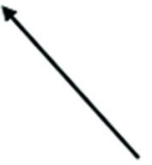

\section{Evasion of neutrophil killing}

- Blockade of neutrophil recruitment (CHIP. Eap)

- Inthibition of antimicrobial peptide killing

(staphylokinase, aureolysin. alteration of bacterial surface charges) - Neutralization of ROS

(catalase, SOD, pigment)

- Neutrophil cytolysis

(PSMs and other toxins)

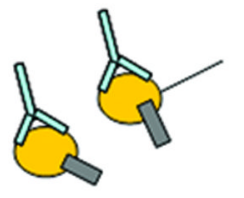

\section{S. aureus}

\section{Evasion of opsonophagocytosis}

(capsule, clumping factor A, protein A. multiple inactivators of complement)

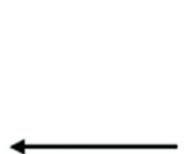

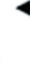

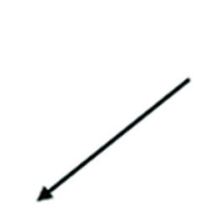

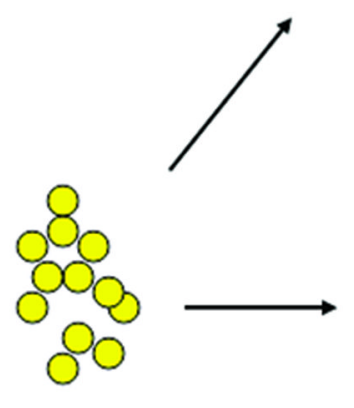
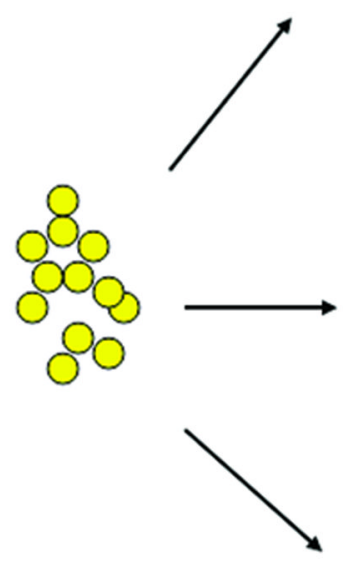

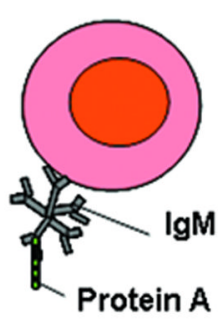

$B$ cell depletion (Protein A)

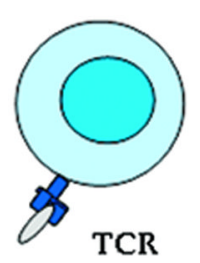

Inactivation of $\mathrm{T}$ cell functions (TSST, Eap, Enterotoxins)

Figure 1. S. aureus survival strategies during infection MSCRAMM, Microbial surface components recognizing adhesive matrix molecules; CHIP, chemotaxis inhibitory protein; Eap, extracellular adherence protein; SOD, superoxide dismutase; PSM, phenol soluble modulin; Isd, iron-regulated surface determinant; TCR, T cell receptor; TSST, toxic shock syndrome toxin. 